\title{
Impact of Backyard Rabbit Rearing among Rural Youth to Enhance the Livelihood Status in Kancheepuram District of Tamil Nadu
}

\author{
K. Devaki ${ }^{1 *}$, K. Senthilkumar ${ }^{2}$ and P. R. Nisha ${ }^{1}$ \\ ${ }^{1}$ Krishi Vigyan Kendra, Kattupakkam, Tamil Nadu Veterinary and Animal Sciences University \\ (Tamil Nadu), India \\ ${ }^{2}$ Pig Breeding Unit, Post Graduate Research Institute in Animal Sciences, Tamil Nadu \\ Veterinary \& Animal Sciences, Kattupakkam- 603 203, India \\ *Corresponding author
}

\section{A B S T R A C T}

\section{Keywords}

Backyard rabbit farming, Frontline Demonstration, extension gap, technology gap

Article Info

Accepted:

07 December 2020

Available Online:

10 January 2021
Rabbit production is one of the livestock enterprises with the greatest potential and room for expansion in Tamil Nadu. This is because of their minimal investment requirements and ability to reproduce fast. Their feed requirement is low, especially with regard to demand for grain. Hence a frontline demonstration on backyard rabbit rearing was conducted at 5 farmer's holdings of Kancheepuram district during 2018-19 to demonstrate the scientific rabbit rearing for getting higher yield and income by the farmers. The New Zealand White Rabbit management practices were demonstrated under front line demonstration and it was compared with farmers practice. The results of the demonstration indicated that demonstration of scientific rearing of rabbits recorded higher yield of 990 gms and farmers practice recorded the lower yield of 650 gms. The increase in the weight of rabbit over farmers practice was 50 per cent. The extension gap of 340 gms recorded for marketing body weight of the New Zealand White between demonstration and farmers practice indicated that dissemination of rabbit rearing practices including scientific management practices through demonstration is needed among the rabbit rearers for achieving higher yield thereby income. It was also found that the mortality rate of rabbits was reduced after advising the farmers on scientific rabbit farming practices. Besides, demonstration of scientific rabbit rearing recorded higher net income of Rs.1265 with benefit cost ratio of 2.22 as against farmers practice wherein, the net income was Rs.408 with benefit cost ratio of 1.91 for every rupee investment.

\section{Introduction}

Rabbit production has experienced a steady growth in the past few years, with gender biases associated with its production fading away. This is a significant change considering that for many years rabbit production in Tamil Nadu was confined to the youth and young farmers. Though rabbit meat marketing is yet to gain ground, there is hope that with the growing awareness of the benefits of rabbit meat, it will be possible for rabbit meat to be introduced into the regular meat market. With the trend shifting from rearing rabbits merely as pets to that of an income generator units with broiler rabbits such as New Zealand White, Soviet Chinchilla, Grey giant and White Giant, rabbit farming has come up as 
an option for alleviating rural poverty among the farming community. This animal could be reared by women folk as well as by children as rabbits are very docile and easy to care.

Rabbits are prolific as each doe is capable of reproducing 4 times a year with an average of 8 bunnies per kindling (Dalle Zotte, 2014). They have one of the highest feed conversion ratios of 4:1. Rabbit meat is white meat of high quality, easily digestible with low fat, low cholesterol and high protein compared to most other meats.

The unsaturated fats (good fats) in rabbit meat make $63 \%$ of the total fatty acids. Rabbit meat is lower in percentage fat than chicken, turkey, beef and pork (Mutsami and Karl, 2020). Rabbit meat provides the lowest calories per kilogram of meat consumed compared to other sources of meat.

Although Rabbit farming is in primitive stage as far as Tamil Nadu is concerned, several farmers are willing to take up rabbitary as an option for getting more output with less input. Hence, a front line demonstration was carried out to popularize backyard rabbit rearing among rural youth to enhance the livelihood status in Kancheepuram district.

The problems encountered in rabbit farming were collected during farm and field visit to rabbit farms, on-campus and off- campus training programmes and mass contact programmes conducted by KVK, Kattupakkam.

Some of the major constraints identified were:-

Lack of training and best farming practices in rabbit production

Lack of awareness on rabbit rearing to enhance income

Non- availability of quality rabbits
Unremunerative price for rabbits

Lack of veterinary aid and medicines

Based on this data, a frontline demonstration (FLD) was proposed by KVK, Kattupakkam to overcome few such constraints in rabbit farming such as low body weight in rabbits by popularization of farm bred New Zealand white rabbits in Kancheepuram district. The New Zealand white rabbits were selected for this FLD because these rabbits are much improved high yielding meat type, highly prolific and they mature quickly and the does (females) can become fertile within their 8-12 weeks of age. In addition, the marketing weight is higher than any other breeds with higher market demand.

\section{Materials and Methods}

Five villages namely Kalvoikandigai, Kattankolathur, Thiruvadisoolam, Karunguzhi and Korukkanthangal were selected for the study. From each village, one farmer was selected for the demonstration. Fifteen rabbits (5 males and 10 females) were procured from Post Graduate Research Institute in Animal Sciences, Kattupakkam for conducting this FLD. Rabbit feed was procured from Central Feed Technology Unit, Kattupakkam. Three rabbits (2 females and 1 male) and $20 \mathrm{~kg}$ rabbit feed was distributed to each selected farmer by KVK, Kattupakkam to conduct the study. Prior to conducting demonstration the beneficiary farmers were educated and demonstrated on the various technological interventions to be followed in the demonstration. The data on birth weight, weaning weight, bunnies mortality and marketing weight were recorded and analysed using simple statistical tools. The traditional practices were adopted in case of local checks. The data were collected from both demonstration plot as well as control (local check) plots and finally the extension gap, technology gap, technology index along with 
the benefit cost ratio were worked out (Samui et al., 2000) as given below:

Percent increase yield $=$ Demonstration yield - farmers yield $\times 100$

Farmers yield

Technology gap = Potential yield Demonstration yield

Extension gap $=$ Demonstration yield Farmer's yield

Technology index $=$ Potential yield - Demo. yield $\times 100$

$$
\text { Potential yield }
$$

\section{Results and Discussion}

Results on the effect of frontline demonstration and farmers practice on the growth and yield of New Zealand white rabbit are given in Table 1. Demonstration of New Zealand White rabbit variety with scientific management practices has recorded higher body weight (990 gms) and reduced mortality rate of bunnies $2.2 \%$. Farmers practice recorded lower marketing body weight of 650 gms and higher mortality rate of bunnies (40\%). Besides, demonstration recorded higher number of young ones (9 Nos.,) and farmer practice recorded lower three number of bunnies. The higher marketing weight observed under demonstration might be due to the good scientific management practices taught during the training. Similar findings were reported by Amin et al., (2011).

It was found that New Zealand white rabbits under backyard rearing had given birth to more number of young ones (9) with improved birth weight (34 gms) and marketing weight (990 gms) at 6-7 weeks of age and reduced mortality rate (2.2\%). Marketing for rabbits are being done through Whatsapp and SMS to other farmers and the rabbits are sold at the farm gate itself.
The recorded rabbit parameters such as birth weight, mortality rate, weaning weight, marketing weight and economic parameters were tabulated and given in Table 2.

It was found that on an average the rabbits attained the weight of around 990 gms. It was also observed that the mortality rate of bunnies was reduced from $40 \%$ to $2.2 \%$ after advising the farmers on scientific rabbit farming practices. Gosh (2009) recorded similar observations for the broiler rabbits. The benefit cost ratio was found to be 2.22 which in turn reveal that rabbit farming is a profitable venture to the farmers. In an average, a total amount of Rs.2300/per animal was obtained by the rabbit farmer by selling the rabbit. This indicates better performance and more feasibility of adoption of improved production technologies of rabbit rearing. Similar findings were also reported by Singh et al., (2018) in barley and chickpea. Besides, demonstration of scientific rabbit rearing recorded higher net income of Rs.1265 with benefit cost ratio of 2.22 as against farmers practice wherein, the net income was Rs.408 with benefit cost ratio of 1.91 for every rupee investment.

The gap between the existing and recommended technologies of rabbit farming in the district was presented in Table-3. In general, farmers are rearing New Zealand White rabbits without scientific intervention. Unavailability of veterinary advice in time and lack of awareness were the main reasons. The technology gap, the difference between potential yield and yield of demonstration plot was $160 \mathrm{gms}$ in rabbit rearing during demonstration period. The technology gap observed may be attributed to dissimilarity in the knowledge level of the rabbit farmers. Singh et al., (2007) observed similar results with regard to the FLD in barley and chicken pea. Extension gap for FLD on rabbit rearing was observed as 340 during demonstration 
period. The recorded extension gap (340 gms) in rabbit rearing emphasized the need to educate the farmers through various means of adoption of improved production and protection technologies to reverse this trend of wide extension gap. More and more use of latest scientific technologies to rear rabbits will subsequently change this alarming trend of galloping extension gap. This finding is in corroboration with the findings of Joshi et al., (2014) and Kumar et al., (2014).

Table.1 Average Marketing weight, Mortality rate and Income from New Zealand White rabbit

\begin{tabular}{|c|c|c|c|c|c|c|}
\hline \multirow{2}{*}{$\begin{array}{l}\text { S. } \\
\text { No. }\end{array}$} & \multirow{2}{*}{$\begin{array}{c}\text { List of } \\
\text { Farmers }\end{array}$} & \multicolumn{5}{|c|}{ Parameters } \\
\hline & & $\begin{array}{l}\text { Birth wt. } \\
\text { (in gms) }\end{array}$ & $\begin{array}{c}\text { Mortality } \\
\text { rate (\%) }\end{array}$ & $\begin{array}{l}\text { Weaning } \\
\text { weight } \\
\text { (in gms) }\end{array}$ & $\begin{array}{l}\text { Marketing } \\
\text { Weight } \\
\text { (in gms/kg) }\end{array}$ & BCR \\
\hline 1 & Farmer-1 & 34 & 2 & 442 & 1.2 & 2.22 \\
\hline 2 & Farmer-2 & 35 & 2 & 460 & 1.1 & 2.22 \\
\hline 3 & Farmer-3 & 31 & 2 & 480 & 900 & 2.22 \\
\hline 4 & Farmer-4 & 32 & 3 & 520 & 800 & 2.22 \\
\hline 5 & Farmer-5 & 40 & 2 & 510 & 950 & 2.22 \\
\hline & Average & 34.4 & 2.2 & 482.4 & 990 & 2.22 \\
\hline
\end{tabular}

Table.2 Rabbit economic parameters

\begin{tabular}{|l|c|c|}
\hline \multicolumn{1}{|c|}{ Parameters } & $\begin{array}{c}\text { Local Check } \\
\text { (Farmers Practice) }\end{array}$ & Demo \\
\hline Mortality rate (\%) & 40 & 2.2 \\
\hline Birth weight (gms) & 28 & 34.4 \\
\hline Marketing weight (gms/kg) & 650 & 990 \\
\hline No.of bunnies (Nos.) & 3 & 9 \\
\hline Gross cost (Rs.) & 442 & 1035 \\
\hline Gross return (Rs.) & 850 & 2300 \\
\hline Net return (Rs.) & 408 & 1265 \\
\hline BCR & 1.91 & 2.22 \\
\hline
\end{tabular}

Table.3 Effect of scientific rabbit rearing on extension gap, technology gap and technological index

\begin{tabular}{|c|c|c|c|c|c|c|c|}
\hline \multicolumn{2}{|c|}{$\begin{array}{l}\text { Under FLD } \\
\text { Programme }\end{array}$} & \multicolumn{2}{|c|}{$\begin{array}{c}\text { Average Yield } \\
\text { (Marketing weight) }\end{array}$} & \multirow[t]{2}{*}{$\begin{array}{c}\% \\
\text { increased }\end{array}$} & \multirow[t]{2}{*}{$\begin{array}{c}\text { Technology } \\
\text { Gap }\end{array}$} & \multirow[t]{2}{*}{$\begin{array}{l}\text { Extension } \\
\text { gap }\end{array}$} & \multirow[t]{2}{*}{$\begin{array}{l}\text { Technology } \\
\text { Index (\%) }\end{array}$} \\
\hline $\begin{array}{l}\text { No. of } \\
\text { Demo }\end{array}$ & $\begin{array}{l}\text { Total No. } \\
\text { of Rabbits }\end{array}$ & Demo & $\begin{array}{l}\text { Farmers } \\
\text { Practice }\end{array}$ & & & & \\
\hline 5 & 15 & 990 & 650 & 52.31 & $160 \mathrm{gms}$ & $340 \mathrm{gms}$ & 13.91 \\
\hline
\end{tabular}

The technology index shows the feasibility of the evolved technology at the farmers' field. Higher technology index reflected the insufficient extension services for transfer of technology. The lower value of technology index shows the efficacy of good performance 
of technological interventions. The average technology index observed in this FLD on rabbit was $13.91 \%$ (Table-3). This variation indicates that the result differ according weather condition and mismanagement of rabbit farming. Similar findings were reported by Joshi et al., (2014) and Kumar et al., (2014).

\section{Horizontal spread}

One of the FLD farmer namely Farmer-2 motivated her village farmers for adoption of rabbit farming to improve their livelihood status. She shares her experiences with the fellow farmers who are all visiting the farm and promote rabbit farming. Three of them had ventured into rabbit farming on her advice and they regularly market their animals in nearby meat selling shops and sometimes they also market their animals at their farm gate on live weight basis. Being a progressive rabbit farmer, she is being invited to $\mathrm{KVK}$ during rabbit farming training programmes to share her experience to the trainees.

\section{Observed Impact of the FLD on backyard rabbit rearing among rural youth}

This FLD on backyard rabbit rearing among rural youth provided the following impact:-

Provides regular income to the farmers

Creates employment generation

Higher market demand

Direct marketing fetches higher return

The farmers income was increased as the marketing weight of the rabbits were increased. The farmers sold the rabbits in the nearby market where there is a great demand. Few farmers used the rabbit meat for household consumption.

In conclusion the backyard rabbit rearing is profitable for small farmers and can be taken on commercial basis with suitable marketing tie -up with retail outlets. The farmers were satisfied in raising these rabbits. Hence awareness was created among the rural youth on rabbit rearing which in turn creates them employment throughout the year to improve their livelihood status. There was a technological gap between technological intervention and existing practices in rabbit rearing due to lack of knowledge and conviction of improved scientific technologies. Technology and extension gap showed that the farmers were not aware about improved package and practices of rabbit production technologies. Therefore it is recommended that the farmers should be made aware of improved technologies through various extension aids (training, demonstration etc.). Technology index which shows the feasibility of the technology demonstrated has depicted good performance of the intervention. The farmer's income was increased as the marketing weight of the rabbits increased. Hence, awareness was created among the rabbit farmers on scientific rabbit rearing which in turn increase their income in considerable amount to improve their livelihood status. Favorable cost benefit ratio was self explanatory of economic viability of the demonstration and convinced the farmers for adoption of scientific intervention imparted.

\section{References}

Amin, M. R., Taleb, M. A., and Rahim, J. (2011). Rabbit farming: A potential approach towards rural poverty alleviation. Research on Humanities and Social Sciences, 1(2): 7-11.

Dalle Zotte, A. (2014). Rabbit farming for meat purposes. Animal Frontiers, 4(4), 62-67.

Ghosh, N. (2009). Mortality pattern in broiler rabbits (Oryctolagus cuniculus) under warm humid conditions of West Bengal, India. Indian Journal of 
Animal Research, 43(2): 127-129.

Joshi N.S, Bariya M.K. and Kunjadia B.B. (2014). Yield gap analysis through front line demonstration in wheat crop. Int. J Sci. Res. Pub, 4(9): 1-3.

Kumar J, Singh Y.P and Rana D.K. (2014). Yield and gap analysis of wheat (Triticum aestivum) productivity in NCR Delhi. Ind. J Ext. Edu. 50(12):56-58.

Mutsami, C., and Karl, S. (2020). Commercial rabbit farming and poverty in urban and peri-urban Kenya. Frontiers in Veterinary Science. 7: 353.

Samui S K, Maitra S, Roy D K, Mondal A K and Saha D (2000). Evaluation on front line demonstration on groundnut (Arachis hypogaea L.). Journal of Indian Society of Coastal Agricultural Research. 18: 180-3.

Singh, R., Dogra, A., Sarker, A., Saxena, A., and Singh, B. (2018). Technology gap, constraint analysis and improved production technologies for yield enhancement of barley (Hordeum vulgare) and chickpea (Cicer arietinum) under arid conditions of Rajasthan. Indian Journal of Agricultural Sciences. 88(2): 273-279.

\section{How to cite this article:}

Devaki, K., K. Senthilkumar and Nisha, P. R. 2021. Impact of Backyard Rabbit Rearing among Rural Youth to Enhance the Livelihood Status in Kancheepuram District of Tamil Nadu. Int.J.Curr.Microbiol.App.Sci. 10(01): 491-496. doi: https://doi.org/10.20546/ijcmas.2021.1001.060 